\title{
ANALISIS MAKNA KANYOUKU \\ YANG MENGGUNAKAN KANJI KOSHI DALAM KODANSHA'S DICTIONARY OF BASIC JAPANESE IDIOMS
}

\section{Felicia}

\author{
Japanese Department, Faculty of Humanities, Bina Nusantara University \\ Jln. Kemanggisan Ilir III No. 45, Kemanggisan - Palmerah, Jakarta 11480 \\ fbudhardja@binus.edu
}

\begin{abstract}
Idiom is quite interesting to discuss since it contains a lot of connotations. This study examined the meaning of kanyouku (idiom) which used koshi (eye) kanji in Kodansha's Dictionary of Basic Japanese Idioms. The method used in this study was library research by collecting data from Kodansha's Dictionary of Basic Japanese Idioms. The purpose of this study was to determine to what extent the use of koshi (hips) in the Japanese idiom was. After analyzing the idiom that uses koshi (hips), the research concludes that the meaning contained in the idiom was connotations.
\end{abstract}

Keywords: analisis makna, idiom, koshi, connotation

\begin{abstract}
ABSTRAK
Sebagai salah satu bagian bahasa, idiom merupakan hal yang cukup menarik untuk dibahas. Dalam idiom, banyak sekali makna konotasi yang terkandung. Tema yang diteliti dalam artikel adalah makna kanyouku (idiom) yang menggunakan kanji koshi (mata) dalam Kodansha's Dictionary of Basic Japanese Idioms. Metode penelitian yang digunakan adalah studi pustaka dengan mengumpulkan korpus data dari Kodansha's Dictionary of Basic Japanese Idioms. Tujuan penelitian untuk mengetahui sejauh mana penggunaan koshi (pinggang) dalam idiom Jepang. Setelah melakukan analisis pada idiom yang menggunakan koshi (pinggang), penelitian menyimpulkan bahwa makna yang terkandung dalam idiom tersebut adalah makna konotasi.
\end{abstract}

Kata kunci: meaning analysis, idiom, koshi, konotasi 


\section{PENDAHULUAN}

Bahasa merupakan lambang bunyi yang arbitrer yang digunakan oleh para anggota masyarakat untuk bekerja sama, berinteraksi, dan mengidentifikasikan diri (Kridalaksana, 2001). Bahasa terdiri atas dua jenis yaitu bahasa lisan dan bahasa tulisan (Felicia, 2007).

Sebagai salah satu bagian dari bahasa Jepang, kanyouku (idiom) merupakan hal yang cukup menarik untuk dibahas. Dalam idiom, banyak sekali makna konotasi yang terkandung.

Inoue (1989) menyatakan:

\section{慣用句というのは二つ以上の語が結び ついて、全体で一つの固決した意味を 表すもので、文中では、一語相当のも のとして用いられる。したがって。個 々の語の意味や文法的な動きとは別個 の存在である。}

Kanyouku adalah gabungan dua kata atau lebih, biasanya mewakili satu makna secara keseluruhan, yang digunakan sebagai suatu kesesuaian dengan satu kata. Oleh karena itu makna dan fungsi gramatikal dari setiap kata mengandung suatu pengertian dari kata lain.

Dalam teori Kanyouku, Kunihiro menyatakan:

\section{言語研究において、文法意論とは別に 慣用句が問題にされるのは慣用句が文 法の一般的な規則ならびに個々語の普 通の意味だけでは律することのできな い性質のものだからえある。」}

Idiom merupakan ungkapan ang dipermasalahkan terkait dengan karakteristik idiom tersebut yang tidak bisa diduga seperti makna kata pada umumnya dengan aturan tata bahasa dan teori semantic bahasa yang bersangkutan.

Sering kali orang salah mengartikan kanyouku karena sifatnya yang tidak dapat diartikan begitu saja berdasarkan kata-kata yang membentuknya. Momiyama (1996) menyatakan bahwa makna kanyouku adalah gabungan dari makna dua kata atau lebih yang sudah ditetapkan. Makna kanyouku yang dihasilkan tidak bisa dicerna berdasarkan makna leksikal maupun makna gramatikal gabungan lata pembentuk kanyouku tersebut.

Makna kanyouku tidak dapat dimasukkan ke kaidah umum gramatikal yang berlaku atau tidak dapat diramalkan dari makna unsur-unsurnya. Namun kanyouku jenis tertentu masih dapat diprediksikan maknanya ditinjau secara historis komparatif dan etimologis, serta asosiasi terhadap lambang yang dipakai karena masih terlihat adanya hubungan antara makna keseluruhan dengan makna leksikal unsur kata pembentuk kanyouku (Aldora, 2012).

Penelitian ini membahas tentang makna kanyouku yang menggunakan kanji me (mata) dalam Kodansha's Dictionary of Basic Japanese Idioms. Metode penelitian yang digunakan adalah penelitian pustaka dengan mengumpulkan korpus data dari Kodansha's Dictionary of Basic Japanese Idiom. Tujuan penelitian ini adalah untuk mengetahui sejauh mana penggunaan koshi (pinggang) dalam idiom Jepang.

\section{METODE}

Metode penelitian yang digunakan adalah studi pustaka dengan mengumpulkan korpus data dari Kodansha's Dictionary of Basic Japanese Idiom. Teori pendukung dijelaskan sebagai berikut.

\section{Semantik}

Semantik dalam bahasa Indonesia berasal dari bahasa Yunani sema (kata benda) yang berarti tanda atau lambang. Kata kerjanya adalah semaina yang berarti menandai atau melambangkan. Jadi, ilmu semantik adalah ilmu yang mempelajari hubungan antara tanda-tanda linguistik dengan hal yang ditandainya. Yang dimaksud dengan tanda atau lambang di sini adalah tanda-tanda linguistik.

Menurut Sausure (2007) tanda linguistik terdiri dari: (1) komponen makna yang menggantikan yang berwujud bunyi bahasa; (2) komponen yang diartikan atau makna komponen pertama. Kedua komponen ini adalah tanda atau lambang. Sedangkan yang ditandai atau dilambangkan adalah sesuatu yang berada di luar bahasa atau yang lazim disebut referen. Jadi ilmu semantik juga dapat dikatakan sebagai: (1) ilmu yang mempelajari hubungan antara tanda-tanda linguistik dengan hal-hal yang ditandainya; (2) ilmu tentang makna atau arti.

Ichiro (1991) seorang ahli semantik modern mengemukakan dalam Aldora (2012) bahwa semantik adalah ilmu yang mempelajari makna dari kata, frasa, dan kalimat. Menurutnya, jika melihat sebuah makna dengan sudut pandang secara objektif maupun secara fisik, banyak hal yang berbeda dan tidak sesuai. Dalam melihat sebuah makna dalam kondisi seperti itu, lebih baik menggunakan sudut pandang secara subjektif. Hal ini karena kata atau kalimat merupakan sesuatu yang digunakan oleh manusia dalam kehidupan sehari-hari dan dari setiap individu akan lahir makna-makna yang berbeda antara satu dengan yang lainnya.

\section{Medan Makna}

Menurut Chaer (2007), yang dimaksud dengan medan makna (semantic domain, semantic field) atau medan leksikal adalah seperangkat unsur leksikal yang maknanya saling berhubungan karena menggambarkan bagian dari bidang kebudayaan atau realitas dalam alam semesta tertentu. Kata-kata atau leksem-leksem yang mengelompok dalam satu medan makna, berdasarkan sifat hubungan semantisnya dapat dibedakan atas kelompok medan kolokasi dan medan set. Kolokasi menunjuk pada hubungan sintagmatik yang terdapat antara kata-kata atau unsur-unsur leksikal itu. Misalnya:

"Tiang layar perahu layar itu patah dihantam badai, lalu perahu itu digulung ombak dan tengelam beserta isinya."

Kata-kata layar, perahu, nelayan, badai, ombak, dan tenggelam merupakan kata-kata dalam satu kolokasi, satu tempat atau lingkungan yang sama, yaitu lingkungan kelautan.

J. Trier dalam Parera (2004) mengatakan bahwa perbendaharaan kata sebuah bahasa tersusun rapi dalam 
medan-medan dan dalam medan itu setiap unsur yang berbeda didefinisikan dan diberi batas yang jelas sehingga tidak ada tumpang tindih antara sesama makna. Ia mengatakan bahwa medan makna itu tersusun sebagai satu mosaik. Setiap medan makna itu akan selalu tercocokan antara sesama medan sehingga membentuk satu keutuhan bahasa yang tidak mengenal tumpang tindih. Sebagai contoh, J. Trier memberikan contoh dengan menurunkan dua medan makna dari kata pandai sebagai berikut:

\begin{tabular}{ll}
\hline Cerdik & Bijak \\
Terpelajar & Berpengalaman \\
Terdidik & Cendikiawan \\
\hline
\end{tabular}

Sumber: Parera (2004)

\section{Denotasi dan Konotasi}

Menurut Keraf (2009), kata yang tidak mengandung makna atau perasaan-perasaan tambahan disebut kata denotatif, atau maknanya disebut makna denotatif. Sedangkan makna kata yang mengandung arti atau tambahan, perasaan tertentu atau nilai rasa tertentu di samping makna dasar yang umum dinamakan makna kotonatif atau konotasi.

Keraf (2008) menyatakan bahwa makna denotatif disebut juga dengan beberapa istilah lain seperti makna denotasional, makna kognitif, makna konseptual, makna ideasional, makna referensial atau makna proposional.

Disebut makna denotasional, referensial, konseptual, atau ideasional karena makna itu menunjuk (denote) kepada suatu referen, konsep atau ide tertentu dari suatu referen. Disebut makna kognitif karena makna itu bertalian dengan kesadaran atau pengetahuan: stimulus dan respon menyangkut hal-hal yang dapat diserap panca indera dan rasio manusia. Makna ini disebut makna proposisional karena bertalian dengan informasi-informasi atau pernyataan-pernyataan yang bersifat faktual.

Makna denotatif dibedakan sebagai relasi antara sebuah kata dengan barang individual yang diwakilinya, dan relasi antara sebuah kata dan cirri-ciri atau perwatakan tertentu dari barang diwakilinya (Keraf, 2009).

Menurut Chaer (2007), makna denotatif adalah makna asli, makna asal atau makna sebenarnya yang dimiliki oleh sebuah leksem. Jadi makna denotaif ini sebenarnya sama dengan makna leksikal.

Makna konotatif disebut juga makna konotasional, makna emotif, atau makna evaluatif (Keraf, 2009). Makna konotatif adalah suatu jenis makna di mana stimulus dan respons mengandung nilai-nilai emosional. Makna konotatif sebagian terjadi karena pembicara ingin menimbulkan perasaan setuju-tidak setuju, senangtidak senang, dan sebagainya pada pihak pendengar. Di lain pihak, kata yang dipilih itu memperlihatkan bahwa pembicaranya juga memendam perasaan yang sama.

Memilih makna konotasi jauh lebih berat jika dibandingkan dengan makna denotasi. Oleh karena itu, pilihan kata atau diksi lebih banyak bertalian dengan pilihan kata yang bersifat konotatif. Jika suatu kata mengandung konotasi yang salah, misalnya kurus-kering untuk menggantikan kata ramping dalam sebuah konteks yang saling melengkapi, makna kesalahan semacam itu mudah diketahui dan diperbaiki. Hal yang sulit adalah perbedaan makna antara kata-kata yang bersinonim tetapi mempunyai perbedaan arti yang besar dalam konteks tertentu (Keraf, 2009).

Sinonim sering dianggap berbeda hanya dalam konotasinya. Dalam kenyataannya terdapat sinonim yang hanya mempunyai makna denotatif, tetapi ada juga sinonim yang mempunyai makna konotatif. Misalnya pada kata mati, meninggal, wafat, gugur, mangkat, berpulang memiliki denotoasi yang sama yaitu peristiwa jiwa seseorang telah meninggalkan badannya. Akan tetapi, kata meninggal, wafat, berpulang mempunyai konotasi tertentu yaitu mengandung nilai kesopanan atau diangggap lebih sopan. Ssedangkan mangkat mempunyai konotasi lain, yaitu mengandung nilai kebesaran dan gugur mengandung nilai keagungan dan keluhuran. Sebaliknya, kata persekot, uang muka atau panjar hanya mengandung makna denotatif (Keraf, 2009).

Chaer (2007) menyatakan bahwa makna konotatif adalah makna lain yang ditambahkan pada makna denotatif tadi yangn berhubungan dengan nilai rasa dari orang atau kelompok yang menggunakan kata tersebut.

\section{HASIL DAN PEMBAHASAN}

\section{Analisis Makna Kanji 「目」secara Denotasi}

Pada bagian ini, penulis menganalisis makna kanji

「目」 secara denotasi sesuai dengan arti yang didapat pada kamus Koujien (1991) Nelson (2001) dan Matsuura (1994). Makna kanji koshi「腰」 secara denotasi:

\begin{tabular}{|c|c|c|}
\hline & Sumber & Makna \\
\hline \multirow[t]{4}{*}{ 腰 } & Koujien & $\begin{array}{l}\text { 人体の脊柱の下部で、骨盤の上の屈折し } \\
\text { 得る部分 } \\
\text { Terjemahan: bagian tubuh yang berada diantara } \\
\text { tulang belakang dan panggul yang bisa dibeng- } \\
\text { kokkan }\end{array}$ \\
\hline & Nelson & Pinggul \\
\hline & & Pangkal paha \\
\hline & Matsuura & Pinggang \\
\hline
\end{tabular}

Dalam Nelson (2001) dan Matsuura (1994), kanji Koshi「腰」 diartikan sebagai pinggang, pinggul, dan pangkal paha . Dalam Koujien (1991), 「腰」 diartikan sebagai bagian tubuh yang berada di antara tulang belakang dan panggul yang bisa dibengkokkan.

\section{Analisis Makna Kanji 「腰」 secara Konotasi}

Pada bagian ini, penulis menganalisis makna kanji

「腰」 secara konotasi sesuai dengan arti yang didapat pada kamus Koujien, Nelson dan Matsuura. Makna kanji koshi「腰」secara konotasi:

\begin{tabular}{|c|c|c|}
\hline & Sumber & Makna \\
\hline \multirow{5}{*}{ 腰 } & \multirow{4}{*}{ Nelson } & $\begin{array}{l}\text { 山のふもとに近いところ } \\
\text { Terjemahan: Tempat yang dekat dengan kaki } \\
\text { gunung }\end{array}$ \\
\hline & & Bingkai \\
\hline & & Lis di bagian bawah dinding \\
\hline & & Batang gelas anggur \\
\hline & Matsuura & Menetap \\
\hline
\end{tabular}


Dalam Nelson, kanji 腰diartikan sebagai bingkai, lis di bagian bawah dinding, dan batang gelas anggur. Dalam Matsuura, kanji 腰 diartikan menetap. Sedangkan menurut Koujien, kanji 腰 diartikan sebagai tempat yang dekat dengan kaki gunung.

Analisis koshi ga takai 「腰が高い」 yang Bermakna "tidak sopan, arogan, sombong, angkuh"

Dalam mencari makna kanyouku「慣用句」koshi ga takai「腰が高い」 terlebih dahulu penulis akan meneliti tiap morfem yang membentuk kanyouku 「慣用 句」 tersebut. Ga merupakan partikel setelah nomina untuk menunjukkan nomina tersebut adalah subjek (Masuoka, 2000). Untuk memahami makna dari kata takai 「高 い」 berikut ini dipaparkan medan makna takai 「高い」 menurut Koujien, Kokugo Jiten dan Matsuura.

Makna takai「高い」menurut Koujien:

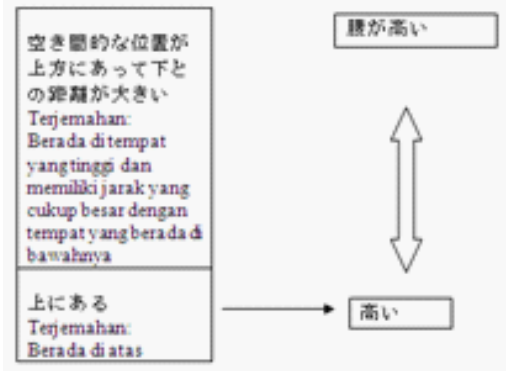

Dalam Koujien, takai 「高い」 diartikan dengan berada di atas. Untuk lebih jelasnya, penulis memberikan medan makna kanji takai 「高い」 menurut Kokugo Jiten sebagai berikut:

Makna Takai「高い」Menurut Kokugo Jiten:

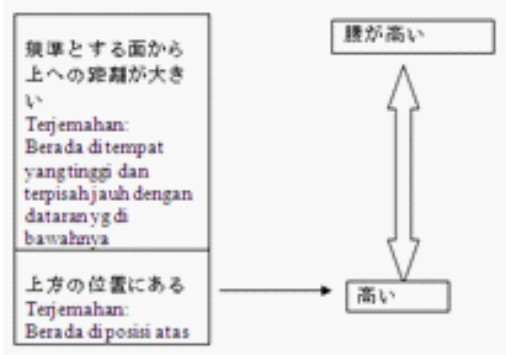

Dalam Kokugo Jiten, takai「高い」 diartikan dengan berada di posisi atas. Untuk lebih jelasnya, penulis akan memberikan medan makna kanji takai「高い」 menurut Matsuura sebagai berikut:

Makna takai「高い」menurut Matsuura

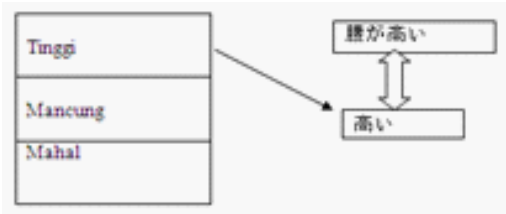

Dalam Matsuura, terdapat satu makna dari takai 「高い」yaitu tinggi. Makna yang sama juga didapat dari Koujien dan Kokugo Jiten. Bila dihubungkan dengan kanyouku「慣用句」koshi ga takai「腰が高い」, hal yang dianggap tinggi adalah sifat arogan atau tidak sopannya seseorang.

Analisis koshi ga nukeru「腰が抜ける」 yang bermakna "kaget hingga tidak dapat bergerak"

Dalam mencari makna kanyouku「慣用句」koshi ga nukeru「腰が抜ける」terlebih dahulu penulis akan meneliti tiap morfem yang membentuk kanyouku「慣用 句」 tersebut. Ga merupakan partikel setelah nomina untuk menunjukkan nomina tersebut adalah subjek (Masuoka, 2000: 49). Untuk memahami makna dari kata nukeru

「抜ける」 berikut dipaparkan medan makna nukeru「 抜ける」 menurut Koujien, Kokugo Jiten dan Matsuura

Makna nukeru「抜ける」menurut Koujien:

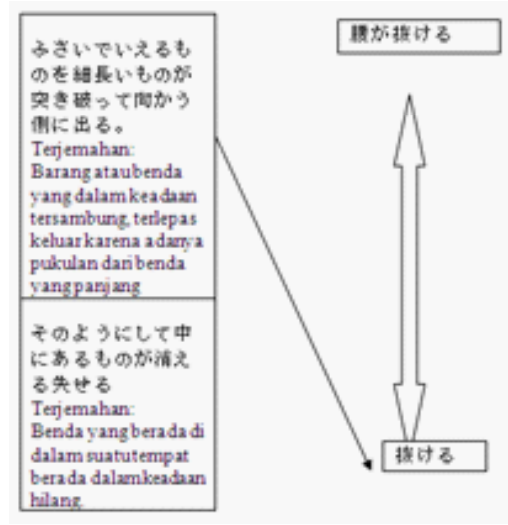

Dalam Koujien, nukeru 「抜ける」 diartikan dengan barang atau benda yang dalam keadaan tersambung, terlepas keluar karena adanya pukulan dari benda yang panjang.

Makna nukeru「抜ける」menurut Kokugo Jiten:

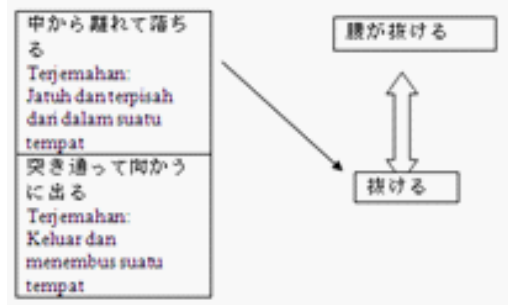

Dalam Kokugo Jiten, nukeru「抜ける」 diartikan dengan jatuh dan terpisah dari dalam suatu tempat.

Makna nukeru「抜ける」menurut Matsuura:

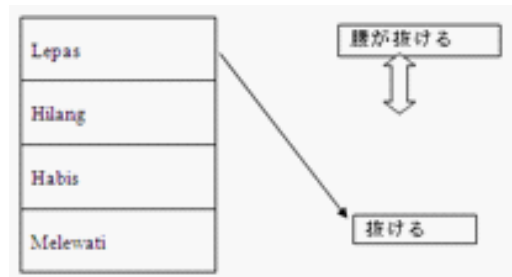

Dalam Matsuura, terdapat makna dari nukeru「抜 ける」 yaitu lepas. Makna tersebut juga didapat dari Kou- 
jien dan Kokugo Jiten. Jika dihubungkan dengan kanyouku「慣用句」koshi ga nukeru「腰が抜ける」, hal yang dianggap lepas adalah perasaan amat sangat terkejut sehingga seolah-olah pinggang terlepas dari badan.

\section{Analisis koshi ga tsuyoi「腰が強い」 yang bermakna} "ulet, tidak mudah menyerah"

Dalam mencari makna kanyouku「慣用句」koshiga tsuyoi「腰が強い」 terlebih dahulu penulis akan meneliti tiap morfem yang membentuk kanyouku「慣用 句」 tersebut. Ga merupakan partikel setelah nomina untuk menunjukkan nomina tersebut adalah subjek (Masuoka, 2000). Untuk memahami makna dari kata tsuyoi「強 い」 di bawah ini adalah medan makna tsuyoi「強い」 menurut Koujien, Kokugo Jiten dan Matsuura.

Makna tsuyoi「強い」 menurut Koujien:

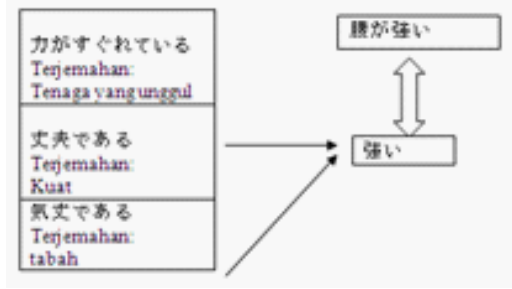

Dalam Koujien, tsuyoi「強い」diartikan sebagai kuat dan tabah.

Makna tsuyoi「強い」menurut Kokugo Jiten:

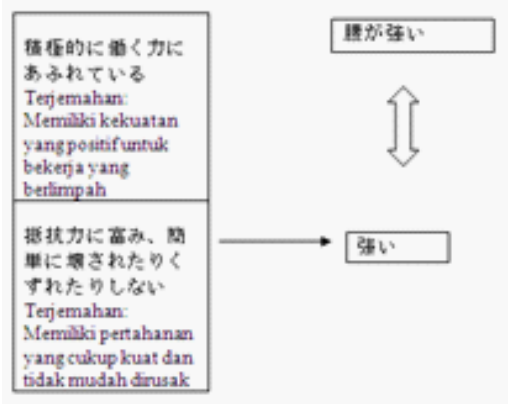

Dalam Kokugo Jiten, tsuyoi「強い」 diartikan dengan memiliki pertahanan yang cukup kuat dan tidak mudah dirusak.

Makna tsuyoi「強い」Menurut Matsuura

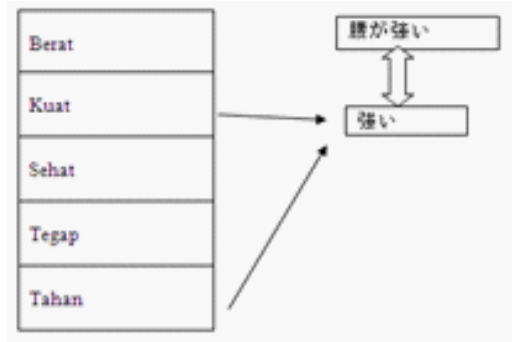

Dalam Matsuura, terdapat makna dari tsuyoi 「 強い」 yaitu kuat dan tahan. Dalam Kokugo Jiten dan Koujien, terdapat pula makna yang sama yaitu memiliki pertahanan yang cukup kuat dan kuat. Jika dihubungkan dengan kanyouku「慣用句」koshi ga tsuyoi「目が回
る」, hal yang dianggap kuat adalah kondisi pinggang yang selalu digunakan untuk menyangga bagian tubuh di atasnya pada saat bekerja. Sedangkan pada makna ulet dan tidak mudah menyerah, dapat diperjelas pada makna tsuyoi pada Koujien yang memiliki arti kuat dan tabah.

\section{SIMPULAN}

Setelah melakukan analisis pada idiom yang menggunakan koshi (pinggang), penelitian menyimpulkan bahwa dalam idiom tersebut, makna yang terkandung di dalamnya adalah makna konotasi. Selain idiom yang menggunakan koshi 「腰」 masih banyak idiom lain yang menarik untuk dibahas. Penulis menyadari bahwa masih banyak kekurangan dalam penelitian ini dan penulis mengharapkan masukan dari pembaca setelah membaca artikel ini.

\section{DAFTAR PUSTAKA}

Aldora. (2012). Analisis Kanyouku Kuchi yang Terdapat dalam Kodansha's Dictionary of Basic Japanese Idioms. Skripsi tidak diterbitkan. Jakarta: Universitas Bina Nusantara.

Chaer, A. (2007). Linguistik Umum. Jakarta: Rineka Cipta.

Keraf, G. (2009). Diksi dan Gaya Bahasa. Jakarta: Gramedia Pustaka Utama.

Matsuura, K. (1994). Kamus Bahasa Jepang-Indonesia. Kyoto: Kyoto Sangyo University Press.

Nelson, A. N. (2001). Kamus Kanji Modern. Jakarta: Kesaint Blanc.

Parera, J. D. (2004). Teori Semantik. Jakarta: Gelora Aksara Pratama.

Pusat Bahasa. (2008). Kamus Besar Bahasa Indonesia. Jakarta: Balai Pustaka. 